\title{
7 An Ayurvedic Approach of Pinda Sweda and its Different Modalities
}

IJCRR
ection: Healthcare
ISI Impact Factor
$(2019-20): 1.628$
SJIF (2020) = 7.893
SIF 90.81
Copyright@IJCRR

\section{Swati Tikale ${ }^{1}$, Krutika Umate ${ }^{2}$, Madhulika Tiwari³, Nikhil Dhande ${ }^{4}$}

\begin{abstract}
'Associate Professor, Panchakarma Department, Datta Meghe Ayurveda Medical College Hospital \& Research Centre, Nagpur, India; ${ }^{2}$ Assistant Professor, Shalakya department, Datta Meghe Ayurveda Medical College Hospital \& Research Centre, Nagpur, India; ${ }^{3}$ Assistant Professor, Sharir Rachana Department, Datta Meghe Ayurveda Medical College Hospital \& Research Centre, Nagpur, India; ${ }^{4}$ Associate Professor, Community Medicine, Jawaharlal Nehru Medical College, Datta Meghe Institute of Medical Sciences Sawangi, Wardha, Maharashtra, India.
\end{abstract}

\section{ABSTRACT}

Swedana (Sudation) is a treatment procedure in which sweat is induced employing heat in the form of steam or by contact of the body with heated medicaments. The effect of Swedana is to relieve stiffness, heaviness and coldness in the body. After Swedana, the body starts sweating and gives the feeling of lightness. The word 'PINDA' means bolus. Pinda Sweda is a traditional Ayurvedic procedure with the property of profound healing and renewal potential. In this procedure, warm cloth boluses which are prepared with herbs, milk, rice, and medicinal leaves, are massaged onto the whole body. Pinda Sweda help to increase circulation improves muscle tone, strengthens the nervous system. According to the patient condition, one can select different types of Pinda Sweda as described in Samhitas and even can make some new combinations as per the need, accessibility and properties of the drugs. The present review study narrates the literature available on Pinda Sweda, which generally used as Panchakarma treatment in Ayurvedic classics and practicable modifications one can make according to the accessibility, need, and condition.

Key Words: Swedana, Pinda Sweda, Panchakarma Chikitsa, Samhitas

\section{INTRODUCTION}

All the Panchakarma procedures divided into three karma i.e. Poorva karma (Pre-operative), Pradhana Karma (operative) and Paschat karma (post-operative). The Swedana karma is included in Poorva karma for Panchakarma procedures. Swedana is the karma that causes the body to perspire. ${ }^{1}$ It can be achieved by many methods. The Sweda karma classified into two types as Sagni Sweda (direct contact with fire) and Niragni Sweda (without the direct contact of fire). ${ }^{2}$ Sankara Sweda is one among the 13 Saagni Sweda. In our classics text, the Sankaradi Sweda is mentioned as one of the most ancient treatments in Ayurveda. ${ }^{3}$ Pinda Sweda works on the principles of Sankara Sweda. Pinda Sweda falls into the category of Tapa Sweda of four types of Sweda. Sankara Sweda is the method in which the materials are wrapped in a cloth and used for Swedana purpose and it is known as Pinda Sweda. ${ }^{4}$ The Sankara Sweda is again classified based on dravya used as Rooksha Sankara Sweda and Snigdha Sankara sweda. In the case of Ruksha (dry) Sankara Sweda, hot solid substances which are used as the stool of different animals like Cow, Horse, Camel, Sand, Brick, Stone and this type Swedana mainly practised in Kapha vitiated patients. ${ }^{5}$ In type of Snigdha (Unctuous) Sankara Sweda, the thick gruel is prepared from the materials like-Tila (Sesame), Masha (Black gram), Kulatha (Horse gram), Amla Dravya (Citric fruits,) Ghrita (ghee), Taila (oil), Payasa (rice and milk pudding) and this Swedana is more practised in the conditions of KevalaVata. ${ }^{6}$ There are varities of Pinda Sweda as Shashtika Shali Pinda Sweda and Nirgundi Patra Pinda.

Depend on the properties of the Dravya utilized for the Swedana karma is of three types Snigdha-Ruksha, Snigdha, Ruksha which are adopted mainly for Vata-Kapha, Vata and Kapha Pradhan Vyadhi respectively. ${ }^{7}$ So we can systematize Pinda Sweda concerning the Guna of Dravyas used (Table $1)$.

\section{Corresponding Author:}

Dr. Swati Tikale, Associate professor, Panchakarma department, Datta Meghe Ayurveda Medical College Hospital \& Research Centre, Nagpur, India.

ISSN: 2231-2196 (Print)

Received: 18.09 .2020
ISSN: 0975-5241 (Online)

Revised: 14.11 .2020
Accepted: 19.12 .2020
Published: 25.04 .2021 
Table 1: Probable Classification of Pinda Sweda according to the Gunas of Dravya used

$\begin{array}{lll}\text { Snigdha } & \text { Ruksha } & \begin{array}{l}\text { Snigdha- } \\ \text { Ruksha }\end{array} \\ \text { Mamsa pinda Sweda } & \text { Valuka pinda Sweda } & \begin{array}{l}\text { Patra pinda } \\ \text { Sweda }\end{array} \\ \text { Masha pinda Sweda } & \begin{array}{l}\text { Tusha / busha pinda } \\ \text { sweda }\end{array} & \begin{array}{l}\text { Jambeer } \\ \text { pinda Sweda } \\ \text { Choorna } \\ \text { pinda Sweda } \\ \text { Chincha } \\ \text { lavana pinda } \\ \text { sweda }\end{array} \\ \begin{array}{l}\text { Shashtika shali pinda } \\ \text { sweda }\end{array} & \text { Karisha pinda Sweda } \\ \begin{array}{l}\text { Godhuma pinda } \\ \text { Sweda }\end{array} & \begin{array}{l}\text { Karpasabeja pinda } \\ \text { sweda }\end{array} & \begin{array}{l}\text { Kod } \\ \hline\end{array}\end{array}$

\section{VALUKA SWEDA}

Valuka sweda is one among the Ruksha sweda. Valuka Sweda is the treatment in which sand is used for fomentation (sweat-inducing) of painful parts. It can be done as Sarvanga (whole-body) or Ekanga (locally) Swedana procedure. It provides relief from pain, inflammation, swelling and stiffness. It is mainly used in Sandhigata Vata (osteoarthritis), Amavata (rheumatoid arthritis), Urustambha (stiffness of the thighs) Obesity, Granthi, Kapha Medavritavata (Table 2). ${ }^{8}$

\section{MATERIALS REQUIRED}

Table 2: Ingredients required for Valuka Sweda

\begin{tabular}{llc} 
SR. No. & Ingredients & Quantity \\
1 & Sand & $1 \mathrm{~kg}$ \\
2 & Cotton cloth $(45 \mathrm{~cm} \mathrm{X} 45 \mathrm{~cm})$ & 4 \\
3 & Tag & 4 \\
4 & Vessel & 1 \\
5 & Rasnadi choorna & $5 \mathrm{gm}$ \\
\hline
\end{tabular}

The Valuka is heated and pottalis are made. It can be applied directly on the body or by dipping into Kanji $i^{9}$. This is very useful in alleviating Vata and Kapha diseases and pain all over the body etc.

\section{Probable Alteration in Valuka Sweda}

Pranipurisha (Stool of animals), Lavana (rock salt), Ishtikachoorna (brick powder), Vatahara Patras, Nirgundi (Vitex negundo), Arka (Calotropis Procera), Agnimantha (Clerodendrum phlomidis), Dhatura (Datura metel), Vatahara choorna, Rasna (Pluchea lanceolata), Devdaru (Cedrous deodara) etc. can be used before applying Taila (NimbaTaila, Brhat Saindhavadi Taila, Sahacharadi Taila).

\section{PATRA PINDA SWEDA}

Patra Pinda Sweda is the type of Pinda Sweda where leaves of medicinal plants that have the property of Vata Kaphaha$r a$ are roasted in a pan with little oil and a bolus is prepared by tying in the cloth ${ }^{10}$. It is one of the types of Ushma Sweda ( Table 3).

\section{Ingredients Required}

Table 3: Materials Required For Patra Pinda Sweda

\begin{tabular}{lc} 
Drugs/ ingredients & Quantity \\
Nirgundi (Vitex negundo) & 1009 \\
Eranda (Ricinus communis) & 1009 \\
Chincha (Tamarindus indica) & 1009 \\
Dhatura (Datura metel) & $25 \mathrm{~g}$ \\
Shigru (Moringa oleifera) & $25 \mathrm{~g}$ \\
Arka (Calotropis procera) & $25 \mathrm{~g}$ \\
Grated coconut & $150 \mathrm{0}\left(\frac{1}{2}\right.$ coconut) \\
Lemon & 4 \\
Cotton cloth $(45 \mathrm{~cm} \mathrm{X} \mathrm{45cm)}$ & 2 pieces \\
Tags & 2 \\
\hline
\end{tabular}

\section{Possible Modifications}

Instead of different combinations of Patras, only single patra pottali can be practised. Eg.- Nirgundi patra pinda sweda, Arka patra pinda sweda and also Anda Sweda, Bhusa Pinda Sweda, Karish Pinda Sweda, etc ${ }^{11}$ can be used in practice. Various choorna combinations can be used.

\section{JAMBEERA PINDA SWEDA}

The word "Jambira Pinda" is made up of two words Jambira means Lemon and Pinda means bolus. Jambira Pinda Sweda assigns to the Pinda Sweda performed by the specially prepared bundles of Jambira and other drugs ${ }^{12}$. This is mainly used in Vata-Kapha morbidity conditions. It is usually practised in Rheumatoid Arthritis, Osteoarthritis, Lumbar Spondylosis, frozen shoulder, plantar fasciitis, and traumatic conditions. It is used in pain, swelling and stiffness associated with joints, spine, nerves etc (Table 4).

\section{Ingredients Required}

Table 4: Ingredients Required For Jambeera Pinda Sweda $^{13}$

\begin{tabular}{|c|c|}
\hline Drugs/Materials & Quantity \\
\hline $\begin{array}{l}\text { Jambeera (Lemon) (around } 20 \text { in number and } \\
\text { chopped into pieces) }\end{array}$ & $750 g$ \\
\hline Saindhava (Rock salt) & 309 \\
\hline Lashuna ( Garlic) & 2009 \\
\hline Turmeric Powder & $6 \circ g$ \\
\hline
\end{tabular}


Table 4: (Continued)

\begin{tabular}{|c|c|}
\hline Drugs/Materials & Quantity \\
\hline Cotton cloth $(45 \mathrm{~cm} \mathrm{X} 45 \mathrm{~cm})$ & 4 \\
\hline Threats & 2 \\
\hline Vessels for heating & 2 \\
\hline Suitable oil for Talam & $10 \mathrm{ml}$ \\
\hline Rasna choorna & $5 \mathrm{~g}$ \\
\hline Suitable oil for Abhyanga & 10oml \\
\hline Oil for reheating the Pottali & Q.S \\
\hline
\end{tabular}

\section{Probable modifications}

Matulunga (Citrus medica) can be used instead of lemon. For frying purpose instead of taila, Vasa (fat) and Majja (bone marrow) of different animals can be used. ${ }^{13}$

\section{SHASHTIKA SHALI PINDA SWEDA}

Shashtika Shali Pinda Sweda is the type of Snigdha Sankara Sweda ${ }^{14}$ which falls into the type of Sagni Sweda ${ }^{15}$. In this procedure of Swedana, Shashtika Shali ${ }^{16}$ (a variety of rice with the medicinal value which is cropped in just 60 days) processed in Kwatha (decoction) of Balamoola (the root of Sida cordifolia) and milk. It is known in Kerala as Navarak$i z h i$. It does the function of Swedana, Snehana and Brimhana (anabolic quality) simultaneously; it is mostly used in Vata vitiated disorders. It also possesses inherent cool property, so can also be advised in moderately vitiated Pitta ( Table 5).

\section{Materials Required}

Table 5: Ingredients required for Shashtika Shali Pinda Sweda

\begin{tabular}{ll} 
Materials/Drugs & Quantity \\
Shashtika Shali & $250 \mathrm{~g}$ \\
Balamoola & $250 \mathrm{~g}$ \\
Water & 4 lit \\
Cow's milk & lit \\
Kora cloth $(45 \mathrm{cmx} 45 \mathrm{~cm})$ & 4 \\
Thread & 4 \\
Vessels & For preparing decoction, rice \\
& and for heating the Pottalis \\
Oil for Thalam & $10 \mathrm{ml}$ \\
Rasna Churna & $5 \mathrm{~g}$ \\
Oil for Abhyanga & $100 \mathrm{ml}$ \\
Therapists & 2 \\
\hline
\end{tabular}

\section{Probable Modifications}

Ashwagandha churna, Rasyan churna, Balya churna, Masha churna, Tila churna, Godhuma (wheat flour) can be added to get more benefits of Shashtika Shali Pinda Sweda.

\section{CHOORNA PINDA SWEDA}

Choorna pinda sweda is one of the types of Ushma sweda. The Churna Pinda Sweda is the treatment in which with the mixture of various choorna combinations like Methika (Fenugreek), Sarshapa (Mustard), Shatapushpa (Anethum graveolens), Jatamansi (Nardostachys jatamansi), Atasi (flax seeds) are used. This procedure can be done in two way; Snigdha and Rooksha. ${ }^{15,16}$

In Snigdha pinda sweda, first Abhyanga with oil is done all over the body and the Pottalis are also heated in oil. In Rooksha Pinda Sweda the Pottalis are directly applied all over the body without Abhyanga. The Procedure can also be modified by dipping Pottali into the steam of different Drava (liquid) dravyas like Dhanyamla in some specific conditions (Table $6)$.

\section{Ingredients Required}

Table 6: Ingredients required for Choorna Pinda Sweda

\begin{tabular}{lc} 
Materials/Drugs & Quantity \\
Suitable choorna $($ coarse/fine) & $1 \mathrm{~kg}$ \\
Cotton Cloth $(45 \mathrm{~cm} \times 45 \mathrm{~cm})$ & 2 \\
Tag & 2 \\
Rasna Choorna & $5 \mathrm{~g}$ \\
\hline
\end{tabular}

\section{NEW ADVANCEMENTS}

Choorna Pinda Sweda with dipping in Dhanyamla shown ingredients in Table 7.

Table 7: Ingridents required for Choorna Pinda Sweda with Dhanyamla Dipping

\begin{tabular}{|c|c|c|}
\hline Materials/Drugs & Ekanga & Sarvanga \\
\hline $\begin{array}{l}\text { Kottamchukkadi } \\
\text { choorna }\end{array}$ & $50 \mathrm{~g}$ & 2009 \\
\hline Kulatha choorna & $50 \mathrm{~g}$ & $200 \mathrm{~g}$ \\
\hline Dhanyamla & $\begin{array}{l}\text { 1L (3ooml-cooking } \\
\text { \& 7ooml-dipping) }\end{array}$ & $\begin{array}{l}\text { 2L(50oml-cooking } \\
\& 1.5 \mathrm{~L} \text {-dipping }\end{array}$ \\
\hline Kora Cotton cloth & $1=(18 ” \times 18 ")$ & $4=(18 " x 18 ")$ \\
\hline Tag & $1=18 ”$ & $4=18 ”$ \\
\hline
\end{tabular}

\section{Dhanyamla Dipping}

The Choorna of above drugs are mixed with $500 \mathrm{ml}$ of $\mathrm{Dh}$ anyamla properly and cooked. The Pottali is dipped in heated Dhanyamla and Swedana was done Ekanga or Sarvanga, up to the achievement of proper symptoms of Swedana. During the procedure, the Dhanyamla should be reheated to maintain the same temperature throughout the procedure. Pottali should be used only one time. 


\section{Probable Modifications}

Different choornas can be used like- Kolakullathadi choorna, Kottamchukadi choorna, Triphaladi choorna or a combination of different single drug choorna. Instead of Dhanyaml, Chincha rasa, Gomutra, Single drug Kashaya, Takra can be used.

\section{CHINCHA LAVANA PINDA SWEDA}

Ingredients required for Chincha lavana pinda Sweda in Table 8

Table 8: Ingredients required for Chincha Lavana Pinda Sweda

\begin{tabular}{lc} 
Materials/Drugs & Quantity \\
Chincha (Tamarindusindica) & $500 g$ \\
Saindhva Lavna & 409 \\
Kottamchukkadi Taila & $500 \mathrm{ml}$ \\
Dhanyamla & $1.5 \mathrm{~L}$ \\
Kora Cotton Cloth & $1=(18 " \times 18 ")$ \\
Tag & $1=18 "$ \\
\hline
\end{tabular}

Other probable Dravyas for Pinda Sweda

Busa, Laja (Puffed grain), Navdhanya (Nine grains), Sarshapa (Mustard seeds), Maize.

\section{CONCLUSION}

Swedana is one of the crucial treatment modality which is useful in the treatment of diseases in the form of Poorvakarma, Pradhana karma as well as Paschata karma. The Materials and drugs mentioned for Swedana each of them have their specific properties and actions, so it should be used depending upon the condition. Already there are many Dravya mentioned by our Acharya, we should select them depending upon Desha, Roga, and availability of Dravya. Pinda Sweda is a widely and mostly practised Swedana procedure where the principle of treatment is based on the combined effect of heat and the medicinal properties of drugs. Hence, based on Roga (disease) and Rogi (patient) one can opt for different combinations of Pinda Sweda according to the availability and properties of the drugs.
Conflict of interest: Nil

Source of funding: Nil

\section{REFERENCES}

1. Jadavaji T. Charaka Samhita of Agnivesha revised by Charaka and completed by Dridhabala, Sutrasthana Chapter 14/13. Varanasi, Chaukhamba Orientalia, 2017;88.

2. Jadavaji T. Charaka Samhita of Agnivesha revised by Charaka and completed by Dridhabala, Sutrasthana Chapter 14/65. Varanasi, Chaukhamba Orientalia, 2017;92.

3. Jadavaji T. Charaka Samhita of Agnivesha revised by Charaka and completed by Dridhabala, Sutrasthana Chapter 14/39. Varanasi, Chaukhamba Orientalia, 2017;90.

4. Jadavaji T. Charaka Samhita of Agnivesha revised by Charaka and completed by Dridhabala, Sutrasthana Chapter 14/41., Varanasi, Chaukhamba Orientalia, 2017;203.

5. Jadavaji T. Charaka Samhita of Agnivesha revised by Charaka and completed by Dridhabala, Sutrasthana Chapter 14/26. Varanasi, Chaukhamba Orientalia, 2017;89.

6. Jadavaji T. Charaka Samhita of Agnivesha revised by Charaka and completed by Dridhabala, Sutrasthana Chapter 14/25. Varanasi, Chaukhamba Orientalia, 2017;89.

7. Jadavaji T. Charaka Samhita of Agnivesha revised by Charaka and completed by Dridhabala, Sutrasthana Chapter 14/8. Varanasi, Chaukhamba Orientalia, 2017;88.

8. Jadavaji T. Charaka Samhita of Agnivesha revised by Charaka and completed by Dridhabala, Sutrasthana Chapter 14/9. Varanasi, Chaukhamba Orientalia, 2017;88.

9. Vasant C. Principles and Practice of Panchakarma. Chapter 9 , Chaukhamba publications, 2015;218.

10. Agnivesha, Charaka. Dridhabala. Chikitsa Sthana, Chapter 15/45. Tripathi Brahmanand (editor). Charaka Samhita with Charaka Chandrika Commentary. Vol-2, Varanasi: Chaukamba Surbharati Prakashan. 2015;551.

11. Surendran E. Panchakarma: a guide to treatment procedure in Ayurveda. 1st Edition, Kottakalam,Varier Ayurveda College, 2006;109.

12. Vasant CP. Principles and Practice of Panchkarma, Chaukhambha Publications, New Delhi 5 th edition. 2015,212-213.

13. Panchakarma Illustrated, Shrinivasa Acharya, Chowkambha Sanskrit Pratistan, Delhi, 2006;459.

14. Jadavaji T. Charaka Samhita of Agnivesha revised by Charaka and completed by Dridhabala, Sutrasthana Chapter 14/41. Varanasi, Chaukhamba Orientalia, 2017;93.

15. Jadavaji T. Charaka Samhita of Agnivesha revised by Charaka and completed by Dridhabala, Sutrasthana Chapter 14/39-40. Varanasi, Chaukhamba Orientalia, 2017; 91.

16. Upadhyaya VY (Ed.). Astanga Hridya, Sutrasthana, Chapter 6/7. Varanasi, India: Chaukhambha Prakashan. 